\title{
Understanding the Oxygen Sensitivity of [FeFe]-Hydrogenase: A Reactive Study of Active Site Mimics and Functional Enzyme
}

\author{
Shanika Yadav ${ }^{\mathrm{a}}$, Sven T. Stripp ${ }^{\mathrm{b}}$, and Ulf-Peter Apfel ${ }^{\mathrm{a}, \mathrm{c}}$ \\ a Inorganic Chemistry I, Ruhr-Universität Bochum, Universitätsstraße 150, 44801 Bochum, \\ Germany. \\ ${ }^{\mathrm{b}}$ Experimental Molecular Biophysics, Freie Universität Berlin, Arnimallee 14, 14195 Berlin, \\ Germany
}

c Department of Electrosynthesis, Fraunhofer UMSICHT, Osterfelder Str. 3, 46047 Oberhausen, Germany.

To whom correspondence should be addressed: $\underline{\text { ulf.apfel@ rub.de and sven.stripp@fu-berlin.de }}$

\begin{abstract}
[FeFe]-hydrogenase is nature's most efficient proton reducing and $\mathrm{H}_{2}$ oxidising enzyme. However, biotechnological applications of the enzyme are currently restricted due to its aerobic sensitivity which is poorly understood. Herein, we spectroscopically investigate four mimics of the active site cofactor, $\mathrm{Fe}_{2}(\mathrm{adt})(\mathrm{CO})_{6-\mathrm{x}}\left(\mathrm{CN}^{-}\right)_{\mathrm{x}}$ and $\mathrm{Fe}_{2}(\mathrm{pdt})(\mathrm{CO})_{6-\mathrm{x}}\left(\mathrm{CN}^{-}\right)_{\mathrm{x}}(\mathrm{X}=1,2)$ as well as two cofactor variants of the $[\mathrm{FeFe}]$-hydrogenase from Chlamydomonas reinhardtii towards their reactivity with $\mathrm{O}_{2}$ and reactive oxygen species, ROS. The amine bearing adt mimic, which is the synthetic precursor molecule of the active site cofactor, was found to be most oxygen sensitive. This highlights the role of hydrogen bonding and proton transfer in aerobic deactivation. Moreover, we observed that the ligand environment around the iron ions has a significant influence on the overall reactivity with $\mathrm{O}_{2}$ and ROS, as the deactivation velocity increased with the exchange of $\mathrm{CO}$ to $\mathrm{CN}^{-}$. In order to mimic the catalytically relevant states, deactivation studies were conducted under acidic conditions. Here, the mimics formed a bridging hydride state, which resisted further oxidation. Thus, the results presented herein shed light on the chemistry of oxygen induced deactivation of [FeFe]-hydrogenase.
\end{abstract}




\section{Introduction}

Renewable energy sources like solar, wind, and hydropower face limitations in storage and transportation and therefore impel researchers to investigate alternatives. Along this line, molecular hydrogen $\left(\mathrm{H}_{2}\right)$ is a facile and clean energy storage and transport molecule. However, an efficient and economic generation based on sustainable pathways has not been achieved yet. Among various proposals, biotechnological $\mathrm{H}_{2}$ generation using homogenous catalysts is one potential pathway. Enzymatic $\mathrm{H}_{2}$ production is at a very early technology readiness level, which is surprising, since hydrogenase enzymes are amongst the most effective $\mathrm{H}_{2}$-forming biocatalysts. Especially, [FeFe]-hydrogenases are potent enzymatic machineries with turnover frequency up to $\sim 21,000 \mathrm{~s}^{-1} .{ }^{1}$ The unrivalled catalytic efficiency of [FeFe]-hydrogenases is attributed to their organometallic cofactor. This so-called H-cluster is an assembly of two distinct iron-sulphur sites connected via a cysteine ligand: a [4Fe-4S] cluster, which participates in electron transfer processes during catalysis and a diiron site (Figure 1).

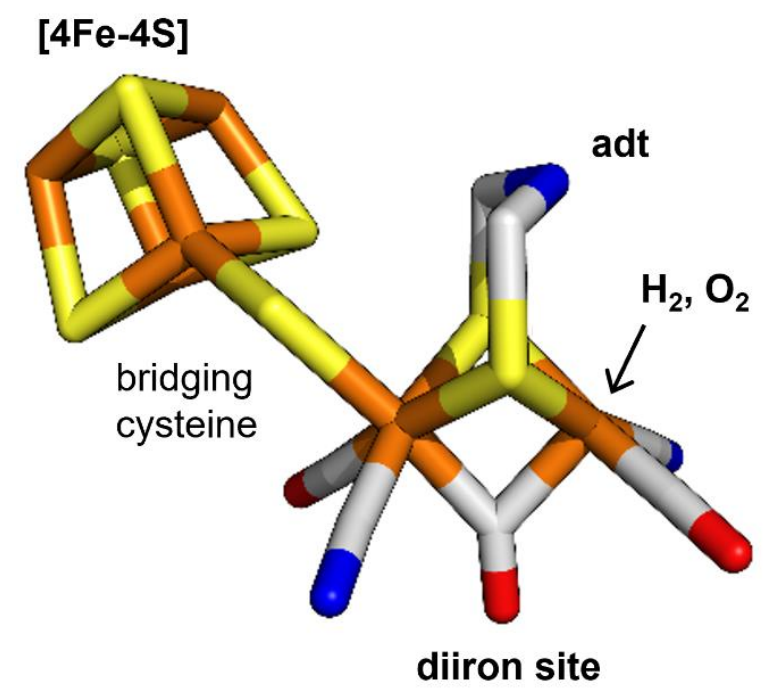

Figure 1 | Stick representation of active site cofactor of [FeFe]-hydrogenase, the 'H-cluster', including a $[4 \mathrm{Fe}-4 \mathrm{~S}]$ cluster connected to the diiron site via a bridging cysteine ligand. The diiron site carries two $\mathrm{CN}^{-}$ligands and three $\mathrm{CO}$ ligands. Reactants like $\mathrm{H}_{2}$ or $\mathrm{O}_{2}$ bind to an open coordination site at the distal iron ion. The adt ligand facilitates proton transfer and functions as hydrogen bond donor. Colour code: orange - Fe; yellow - S; grey - C; blue - N; red - $\mathrm{O}$.

The unique diiron site, where the proton reduction reaction occurs, carries an 'azadithiolate' ligand (adt) and two $\mu \mathrm{CO}$ bridged iron ions, each of which is coordinated additionally to a $\mathrm{CN}^{-}$ and a CO ligand. The adt ligand functions as an internal hydrogen bond donor and proton 
transfer site, coupling bidirectional proton transfer across the protein fold to proton reduction at an open coordination site at the distal iron ion, $\mathrm{Fe}_{\mathrm{d}}$ (Figure 1). Unfortunately, the remarkable proton reduction efficiency of [FeFe]-hydrogenase and its application in energy conversion is severely hindered by the oxygen sensitivity of the enzyme. Therefore, it is important to investigate the oxidative degradation pathways of the enzyme.

While prototypical $[\mathrm{FeFe}]$-hydrogenases like $C r \mathrm{HydA} 1, D d \mathrm{HydAB}$, and $C p \mathrm{I}$ show fast and irreversible deactivation in the presence of $\mathrm{O}_{2}, C b A 5 \mathrm{H}$ from $C$. beijerinckii is reversibly inhibited under aerobic conditions. ${ }^{2,3} \mathrm{CbA} 5 \mathrm{H}$ resists oxygen deactivation by forming the $\mathrm{H}_{\text {inact }}$ state, wherein a conserved cysteine residue blocks the open coordination site of $\mathrm{Fe}_{\mathrm{d}}$. Under $\mathrm{O}_{2}-$ depleted conditions, the active-ready $\mathrm{H}_{\mathrm{ox}}$ state is regained, thus suggesting that the interconversion is reversible. ${ }^{4,5}$ Furthermore, the sensory hydrogenase TamHydS from $T$. mathranii displays sluggish inhibition kinetics, which has been explained by insufficient proton transfer as a sub-step in the deactivation reaction. ${ }^{6}$ Oxygen tolerance and a catalytic reduction of $\mathrm{O}_{2}$ to water like in some [NiFe]-hydrogenases has never been observed with [FeFe]hydrogenase. ${ }^{7,8}$

In order to understand the reaction with $\mathrm{O}_{2}$, numerous theoretical and spectroscopic studies were performed suggesting diffusion of $\mathrm{O}_{2}$ through an unselective hydrophobic gas channel into the enzyme. ${ }^{9-11}$ Initially, $\mathrm{O}_{2}$ interacts with the diiron site at $\mathrm{Fe}_{\mathrm{d}}$, undergoes reductive activation, and is converted to $\mathrm{ROS}$, i.e., $\mathrm{H}_{2} \mathrm{O}_{2}$ or $\mathrm{O}_{2}^{-}$. Subsequently, the ROS damage both the diiron site and the $[4 \mathrm{Fe}-4 \mathrm{~S}]$ cluster, which results in a rapid decline of enzymatic activity. ${ }^{12-15}$ Inhibition experiments with exogenous $\mathrm{CO}$ revealed that $\mathrm{CO}$ binding at $\mathrm{Fe}_{\mathrm{d}}$ shields the $\mathrm{H}$ cluster against oxidative damage. ${ }^{14-16}$ These experiments suggested that $\mathrm{Fe}_{\mathrm{d}}$ is the initial $\mathrm{O}_{2}$ binding site; however, the individual steps of cluster degradation remained unidentified.

Several diiron site mimics were designed and studied towards their proton reduction mechanism. ${ }^{17}$ However, reports on their oxygen reactivity are still rare. ${ }^{18-21}$ In addition, mainly the hexacarbonyl-type diiron complexes were studied, and so far no $\left[\mathrm{Fe}_{2}(\mathrm{xdt})(\mathrm{CO})_{4}(\mathrm{CN})_{2}\right]^{2-}$ type complex has been probed regarding its reactivity with oxygen species. For example, Darensbourg and co-workers reported on the site specificity of the oxygenation of complexes of the type $\mathrm{Fe}_{2}(\mathrm{pdt})(\mathrm{CO})_{6-\mathrm{x}}(\mathrm{L})_{\mathrm{x}}\left(\mathrm{L}=\mathrm{CO}, \mathrm{PMe}_{3}, \mathrm{PPh}_{3} ; \mathrm{x}=1\right.$ or 2) with m-chloroperoxybenzoic acid. Although DFT calculations suggested formation of a thermodynamically favoured $\mathrm{Fe}-$ $\mu \mathrm{O}-\mathrm{Fe}$ bond species, experimental studies revealed a dithiolate sulphur centred oxidation resulting exclusively in S-oxygenate reaction products. ${ }^{18}$ Similarly, Weigand and co-workers reported on the chemical sulphur-oxidation of $\mathrm{Fe}_{2}(\mathrm{sdt})(\mathrm{CO})_{6}$ type models with varying 
equivalents of dimethyldioxirane (DMD). ${ }^{19}$ Furthermore, Dey and co-workers, reported hexacarbonyl diiron active site models that electrocatalytically convert $\mathrm{O}_{2}$ under reductive conditions. ${ }^{20}$ Herein, formation of $\mathrm{H}_{2} \mathrm{O}_{2}$ was observed and the bridgehead amine was suggested to be of key importance to protect the H-cluster from further oxidative damage. Along this line, Berggren, Hammerström and co-workers recently conducted oxidative studies on the hexacarbonyl diiron mimics $\mathrm{ADT}_{\mathrm{CO}}$ and $\mathrm{PDT}_{\mathrm{CO}}$ with $\mathrm{O}_{2}$ and ROS. Here, the interaction of $\mathrm{Fe}_{2}(\mathrm{adt})(\mathrm{CO})_{6}$ with $\mathrm{O}_{2}$ in presence of chemical reductants leads to a transient degenerated state of unknown chemical structure. ${ }^{21}$

In this work, we extend the current reactivity studies and display the oxygen reactivities of complexes $\mathrm{ADT}_{\mathrm{CN}}[1]$ and $\mathrm{PDT}_{\mathrm{CN}}[2]$ to receive a deeper understanding of the aerobic deactivation of [ $\mathrm{FeFe}]$-hydrogenases (Figure 2). Making use of artificial maturation protocols, complexes [1] and [2] were additionally probed as part of the H-cluster within functional [FeFe]-hydrogenase $C r H y d A 1^{\text {adt }}$ and cofactor variant $C r H y d A 1^{\text {pdt }}$. Furthermore, we tested the mono cyanide counterparts $\mathrm{ADT}_{\text {mono-CN }}[3]_{\text {and }} \mathrm{PDT}_{\text {mono-CN }}[4]$, following potential trends of oxygen sensitivity with increasing number of $\mathrm{CN}^{-}$ligands (Figure 2). Among the various oxygen species, superoxide $\left(\mathrm{O}_{2}^{-}\right)$is the most likely ROS affecting iron-sulphur clusters in natural systems, and it is a much stronger one-electron oxidant than $\mathrm{O}_{2}(+0.9 \mathrm{~V}$ and $-0.1 \mathrm{~V}$ vs RHE, respectively). ${ }^{14}$ Moreover, in natural systems, formation of $\mathrm{H}_{2} \mathrm{O}_{2}$ is rather feasible and is considered a harmful substrate for the enzyme. ${ }^{22,23}$ Herein, we report on the interactions of complexes [1]-[4] and $C r \mathrm{HydA} 1$ cofactor variants with superoxide, $\mathrm{H}_{2} \mathrm{O}_{2}$, and $\mathrm{O}_{2}$ by use of FTIR, NMR, as well as Mössbauer spectroscopic techniques. We find that proton transfer and hydrogen bonding with the adt ligand critically influence the oxygen sensitivity.
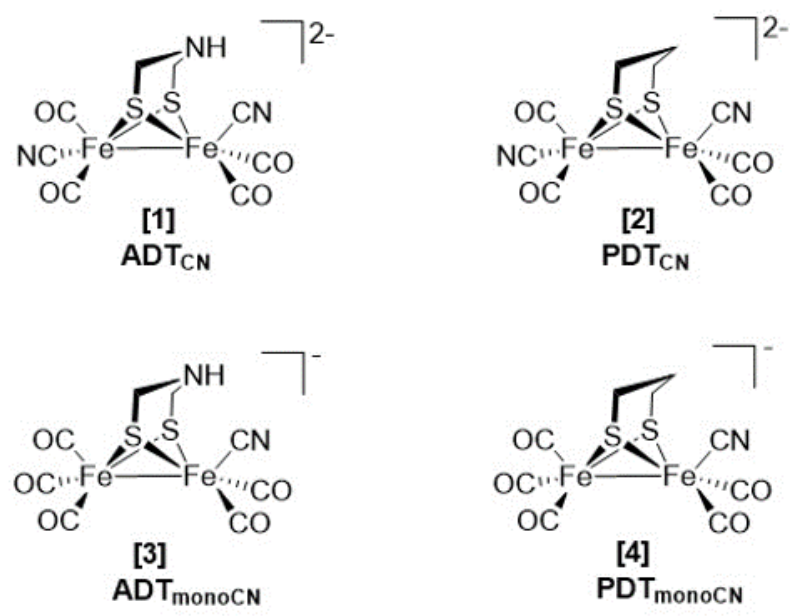

Figure 2 | Schematic drawings of the active site models investigated in the current study. 


\section{Results and Discussion}

Four active site models [1]-[4] were synthesised following previously reported protocols. ${ }^{24,25}$ The reactivity of $\mathrm{ADT}_{\mathrm{CN}}[1], \mathrm{PDT}_{\mathrm{CN}}[2], \mathrm{ADT}_{\text {mono-CN }}[3]$, and $\mathrm{PDT}_{\text {mono-CN }}[4]$ towards the different oxygen species was then investigated upon bubbling pure $\mathrm{O}_{2}$ through the respective solutions or by addition of the specific ROS.

Reaction of model complexes with $\mathbf{O}_{2}$. Prepared in the absence of $\mathrm{O}_{2}$, complex [1] and [2] revealed nearly identical FTIR spectra in the frequency regime of the $\mathrm{CO}$ and $\mathrm{CN}^{-}$ligands between 2150-1800 $\mathrm{cm}^{-1}$ (Figure 3AB and Table 1). These bands have been assigned to the individual $\mathrm{CN}^{-}$stretches and the coupled $\mathrm{CO}$ vibrations. ${ }^{24}$ Severe changes were observed upon purging the solutions with $\mathrm{O}_{2}$. The $\mathrm{CO}$ and $\mathrm{CN}^{-}$bands lose intensity suggesting decomposition of the complexes within tens of minutes (Figure 3). The insets trace the decline of the CO band at $1890 \mathrm{~cm}^{-1}$ and $1884 \mathrm{~cm}^{-1}$ for complex [1] and [2], respectively, revealing a faster reaction with $\mathrm{O}_{2}$ for complex [1] as compared to complex [2]. The FTIR spectrum observed for [1] after 90 minutes indicates a number of broad features spanning from 1930-2000 $\mathrm{cm}^{-1}$ along with better defined peaks at 1998, 2036, 2058, and $2102 \mathrm{~cm}^{-1}$ (second derivative FTIR spectrum below Figure 3A and Table 1). As for [2], sharper and more defined signals emerge at 1972, 2000, 2018, and $2090 \mathrm{~cm}^{-1}$ after 90 minutes (second derivative FTIR spectrum below Figure 3B and Table 1). After 23 hours, the reaction with $\mathrm{O}_{2}$ is finished and no further changes were observed in the FTIR spectra of both complexes (Figure S1). Apparently, the reaction with $\mathrm{O}_{2}$ does not lead to full decomposition of the complexes. In contrast to [1] and [2], the mono cyanide complexes [3] and [4] show no distinct changes upon exposure to $\mathrm{O}_{2}$ (Figure S2), which is in line with previous reports that state that complexes [1] and [2] are easier to oxidise than their mono cyanide derivates. ${ }^{26}$ 
(A)

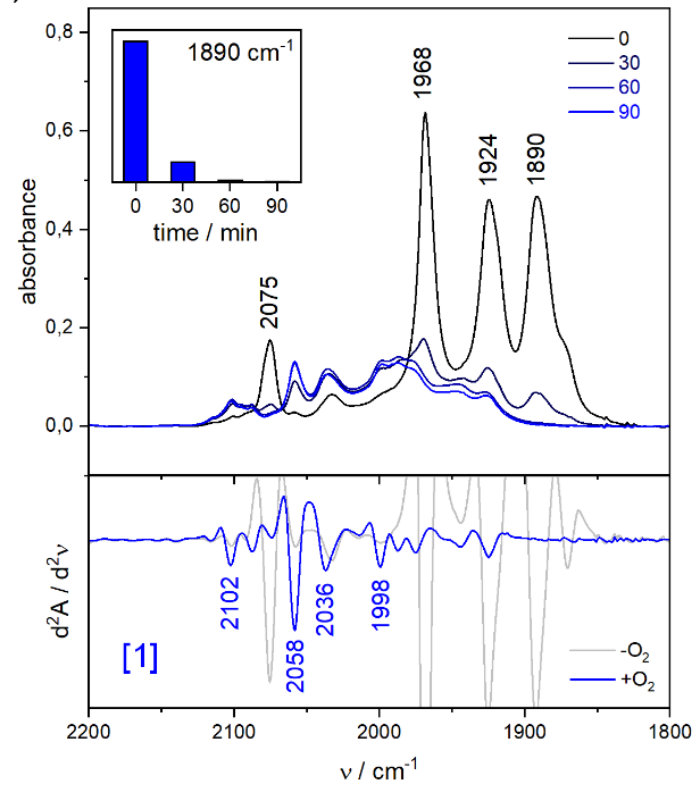

(B)

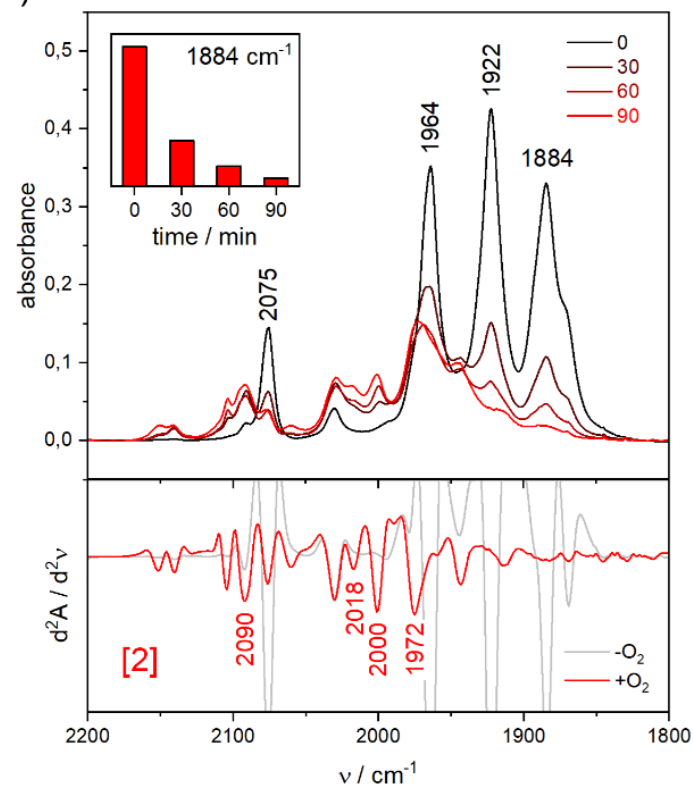

Figure 3 | (A) FTIR spectra of $\mathrm{ADT}_{\mathrm{CN}}$ [1] and (B) PDT $_{\mathrm{CN}}$ [2] upon $\mathrm{O}_{2}$ purging for 30 seconds, recorded in four steps between 0-90 min. Below each absorbance spectrum, the second derivative spectrum at $0 \mathrm{~min}\left(-\mathrm{O}_{2}\right)$ and $90 \mathrm{~min}\left(+\mathrm{O}_{2}\right)$ is plotted to identify the bands of the $\mathrm{O}_{2-}$ oxidised complexes.

Table 1 | Observed IR frequencies and band shifts. All bands are assigned to either $v \mathrm{CO}$ or $\nu \mathrm{CN}^{-}$coupled vibrations. While the mean $\mathrm{CO}$ band shifts between [1] and [2] are small under anaerobic conditions $\left(-\mathrm{O}_{2}, \Delta=-4 \mathrm{~cm}^{-1}\right)$ and in protonated form $\left(\mathrm{TsOH}, \Delta=-1 \mathrm{~cm}^{-1}\right)$ they increase to $\Delta=-34 \mathrm{~cm}^{-1}$ under aerobic conditions $\left(+\mathrm{O}_{2}\right)$. The mean $\mathrm{CO}$ band shift upon oxidisation is $\Delta \mathrm{O}_{2}=+103 \mathrm{~cm}^{-1}$ for [1] and $\Delta \mathrm{O}_{2}=+73 \mathrm{~cm}^{-1}$ for [2]. The mean $\mathrm{CO}$ band shift upon protonation is $\Delta \mathrm{H}^{+}=+94 \pm 1 \mathrm{~cm}^{-1}$ for both complexes.

\begin{tabular}{c|ccc|ccc|ccc} 
& \multicolumn{3}{|c|}{$-\mathrm{O}_{2}$} & \multicolumn{3}{|c|}{$+\mathrm{O}_{2}$} & \multicolumn{3}{|c}{ TsOH } \\
\hline complex & {$[1]$} & {$[2]$} & $\boldsymbol{\Delta}$ & {$[\mathbf{1}]$} & {$[2]$} & $\boldsymbol{\Delta}$ & {$[1]$} & {$[2]$} & $\boldsymbol{\Delta}$ \\
\hline$\nu \mathrm{CO} 1$ & 1890 & 1884 & -6 & 1998 & 1972 & -26 & 1988 & 1984 & -4 \\
$\nu \mathrm{CO} 2$ & 1924 & 1922 & -2 & 2036 & 2000 & -36 & 2024 & 2024 & 0 \\
$\nu \mathrm{CO} 3$ & 1968 & 1964 & -4 & 2058 & 2018 & -40 & 2048 & 2048 & 0 \\
$\nu \mathrm{CN}^{-}$ & 2075 & 2075 & 0 & 2102 & 2090 & -12 & 2106 & 2106 & 0
\end{tabular}

The large $\mathrm{CO}$ band shifts $\left(83 \pm 29 \mathrm{~cm}^{-1}\right)$ towards higher frequencies for both complexes indicate an oxidation of the diiron core. While the spectra of [1] and [2] after exposure to $\mathrm{O}_{2}$ suggest the presence of different species (with a mean difference of $-33 \pm 7 \mathrm{~cm}^{-1}$ for the $\mathrm{CO}$ bands), the obtained $\mathrm{O}_{2}$-oxidised products seem to share a similar structure, which is evident from the 
overall comparable band positions. Thus, Mössbauer spectroscopy was performed to analyse the obtained products. The Mössbauer spectra of complex [1] and [2] after $\mathrm{O}_{2}$ exposure for 30 seconds, result in two quadrupole doublets (Figure 4 and Table 2) that significantly differ from the starting materials (Figure S3). For both complexes an increase of the isomer shift is notable, indicating the oxidation of the iron site to afford $\mathrm{Fe}^{\mathrm{II}}$ centers. However, while one site reveals a high quadrupole splitting and isomer shift, the second site shows smaller values for both parameters (Table 2), suggesting that the metal centres in both complex [1] and [2] have a similar oxidation $\mathrm{Fe}^{\mathrm{III}} / \mathrm{Fe}^{\mathrm{II}}$ state. However it is important to note here that interpretation of Mössbauer spectra of the low spin iron complex with a non-innocent ligand such as $\mathrm{CN}^{-}$is complicated. $^{27}$

(A)

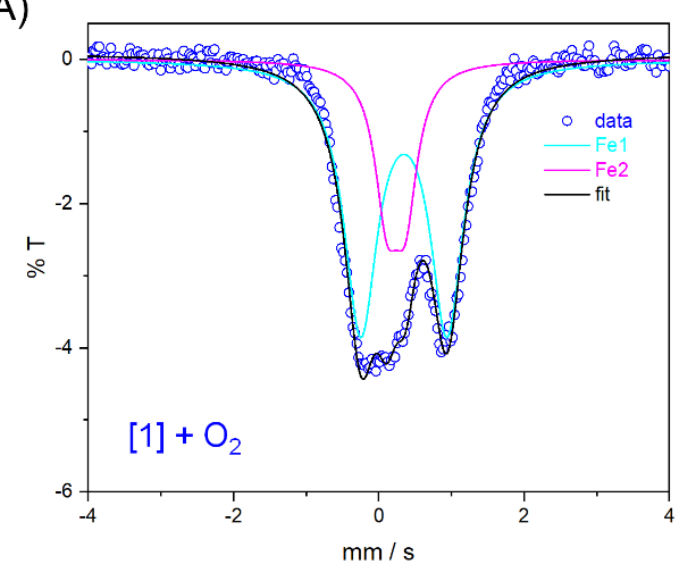

(B)

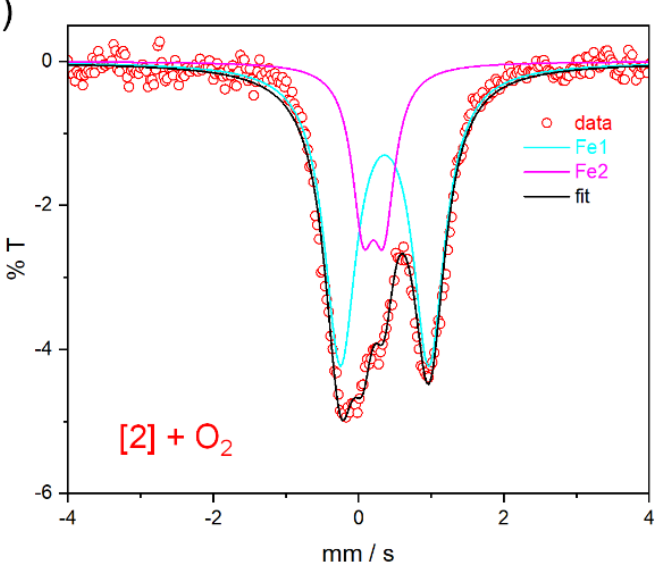

Figure 4 | (A) Mössbauer spectra of $\mathrm{ADT}_{\mathrm{CN}}$ and (B) $\mathrm{PDT}_{\mathrm{CN}}$ upon $\mathrm{O}_{2}$ purging for 30 seconds 
Table 2 | Comparison of isomer shift and quadrupole splitting.

\begin{tabular}{c|c|cc|c|cc} 
& {$[\mathbf{1}]-\mathbf{O}_{2}$} & \multicolumn{2}{|c|}{$[\mathbf{1}]+\mathbf{O}_{\mathbf{2}}$} & {$[\mathbf{2}]-\mathbf{O}_{\mathbf{2}}$} & \multicolumn{2}{|c}{$[\mathbf{2}]+\mathbf{O}_{2}$} \\
\hline iron & $\mathrm{Fe} 1$ & $\mathrm{Fe} 1$ & $\mathrm{Fe} 2$ & $\mathrm{Fe} 1$ & $\mathrm{Fe} 1$ & $\mathrm{Fe} 2$ \\
\hline $\boldsymbol{\delta}$ & 0.037 & 0.238 & 0.345 & 0.035 & 0.204 & 0.358 \\
$\mathbf{\Delta} \mathbf{E}_{\mathbf{q}}$ & 1.109 & 0.253 & 1.188 & 0.951 & 0.288 & 1.219
\end{tabular}

Infrared and Mössbauer spectroscopy demonstrated that both complexes directly react with $\mathrm{O}_{2}$ wherein oxygen binding to the metal centre is followed by spontaneous oxidation of the complex. Such observations were previously reported for the amino acid variants of [FeFe]hydrogenase $\mathrm{CrHydA} 1$ that showed only limited proton transfer. The resulting superoxidebinding state, $\mathrm{H}_{\mathrm{ox}}-\mathrm{O}_{2}{ }^{-}$, was suggested to be unreactive provided no further protonation occurs. ${ }^{28}$ The differences in the FTIR spectra of complex [1] and [2] upon reaction with $\mathrm{O}_{2}$ can be explained as follows: in both cases, $\mathrm{O}_{2}$ interacts with the metal centres forming a metal-oxygen transient state, accompanied by electron transfer(s) to oxygen. Further degradation pathways diverge depending on the nature of the bridgehead. In case of complex [1], the transfer of a pendant proton via the amine to the $\mathrm{CN}^{-}$ligand of the intermediate $\mathrm{Fe}-\mu \mathrm{O}-\mathrm{Fe}$ species (Figure 5, pathway I) may accelerate the deactivation processes. This includes a transient intermediate with an apical $\mathrm{CN}^{-}$hydrogen-bonded to the adt ligand and an oxidation of both iron ions. Another pathway of degradation may include end-on binding of $\mathrm{O}_{2}$ to one of the metal centres (Figure 5, pathway II), not unlike $\mathrm{H}_{\mathrm{ox}}-\mathrm{O}_{2}{ }^{-28}$ This comprises a hydrogen-bonded peroxo anion and oxidation of the coordinating iron site. Thereafter, a highly reactive iron-oxo species is formed which may abstract the protons from the amine bridgehead resulting in formation of a degraded product(s). ${ }^{22,29}$ Since complex [2] lacks the hydrogen-bonding donor and proton relay, a slower decomposition process is expected that would explain the kinetic differences (Figure 3). 


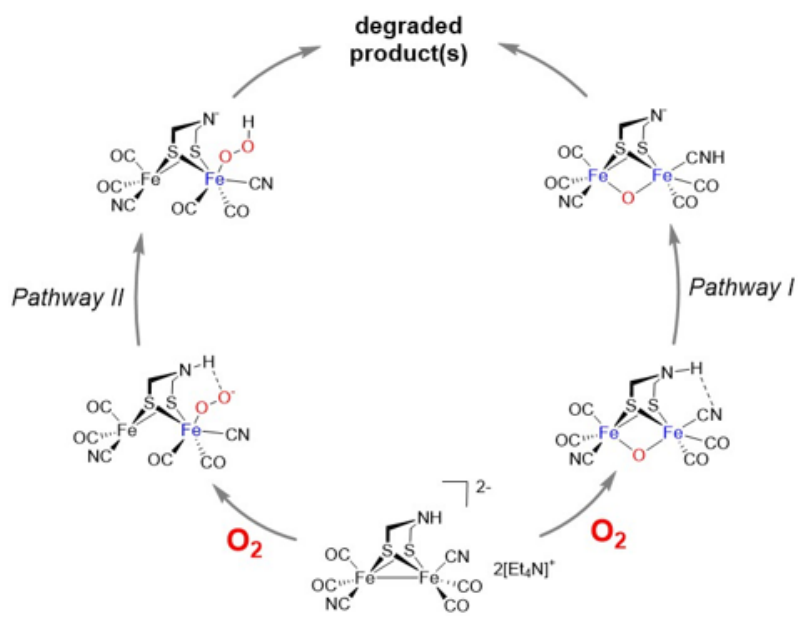

Figure 5 | Postulated degradation pathway via formation of a $\mathrm{Fe}^{\mathrm{II}}-\mu \mathrm{O}-\mathrm{Fe}^{\mathrm{II}}$ state (Pathway I) or via an end-on oxygen binding mixed valence state (Pathway II). Colour code for the Fe ions: black $\left(\mathrm{Fe}^{\mathrm{I}}\right)$ and blue $\left(\mathrm{Fe}^{\mathrm{II}}\right)$.

Reactivity with ROS. To further investigate this hypothesis, we conducted reactions of $\mathrm{ADT}_{\mathrm{CN}}$ and $\mathrm{PDT}_{\mathrm{CN}}$ with excessive equivalents of $\mathrm{KO}_{2}$ as a source of a superoxide. ${ }^{30}$ Notably, no spectroscopic changes were observed (Figure S4), further supporting the idea of an initial electron transfer step to $\mathrm{O}_{2}$ from the diiron site. Considering the strong one-electron oxidative nature of the superoxide anion, it seems reasonable to assume that electron transfer(s) to $\mathrm{O}_{2}$ from [1] or [2] is required to allow for any subsequent binding to occur. This observation would also be in agreement with the electrochemical $\mathrm{O}_{2}$ reduction reaction observed by Dey and coworkers. ${ }^{20}$ Remarkably, these observations suggest that the metal-oxygen interaction is not limited to the presence of an open binding site at the active site but rather is precisely influenced by the ligand environment of the cluster. ${ }^{14,15,31}$

$\mathrm{H}_{2} \mathrm{O}_{2}$ can be formed after reduction and protonation of $\mathrm{O}_{2}$ and is anticipated to be a major ROS for the subsequent decomposition. Therefore, we spectroscopically monitored the reactivity of complexes [1]-[4] with $\mathrm{H}_{2} \mathrm{O}_{2}$. Figure $\mathbf{S 5}$ shows the differences in reactivity of complexes [1] and [2] with different equivalents of $\mathrm{H}_{2} \mathrm{O}_{2}$; both complexes show no response to substoichiometric equivalents of $\mathrm{H}_{2} \mathrm{O}_{2}$. However, ADT $\mathrm{CN}$ is found to be more susceptible towards oxidation with $\mathrm{H}_{2} \mathrm{O}_{2}$ as it reacts with four equivalents of $\mathrm{H}_{2} \mathrm{O}_{2}$ while it takes at least six equivalents of $\mathrm{H}_{2} \mathrm{O}_{2}$ to convert $\mathrm{PDT}_{\mathrm{CN}}$ into an oxidised species with $\mathrm{CO}$ and $\mathrm{CN}^{-}$not unlike those reported for the reaction with $\mathrm{O}_{2}$ (Figure 3). The Mössbauer spectra observed for both complexes upon $\mathrm{H}_{2} \mathrm{O}_{2}$ treatment reveal similar $\delta$ values and are comparable to the ones observed after reaction with $\mathrm{O}_{2}$ (Figure S6). Based on previous reports, the presence of 
$\mathrm{Fe}^{\mathrm{IV}} / \mathrm{Fe}^{\mathrm{II}}$ can be postulated. ${ }^{27,32}$ Additionally, complex [3] also degrades in presence of $\mathrm{H}_{2} \mathrm{O}_{2}$ whereas complex [4] does not react with $\mathrm{H}_{2} \mathrm{O}_{2}$ at all (Figure S7).

Compared to the $\mathrm{O}_{2}, \mathrm{H}_{2} \mathrm{O}_{2}$ reacts more pugnaciously with the complexes. There are several possibilities of interaction of $\mathrm{H}_{2} \mathrm{O}_{2}$ with the metal centre as well as with the thiolate bridge. For example, based on an earlier report by Reiher and co-workers, the reaction of the bridging sulphur atom with $\mathrm{H}_{2} \mathrm{O}_{2}$ is most likely. ${ }^{23}$ However, the metal interaction cannot be completely ruled out considering the obtained FTIR spectra. In our experiments the influence of the amine bridgehead is evident from the overall diminished reactivity of complex [2] compared to [1].

Reactivity in presence of protons and oxygen. As a proton reducing enzyme, [FeFe]hydrogenase cycles through various catalytic intermediates, shuttling protons. Moreover, the $\mathrm{O}_{2}$ sensitivity significantly depends on the availability of protons at the H-cluster. ${ }^{13,33}$ Therefore, the active site mimics were tested towards $\mathrm{O}_{2}$ sensitivity in the presence of protons. Acids with varying strength were employed. Firstly, studies were carried out using acetic acid (23 $p \mathrm{~K}_{\mathrm{a}}$ in $\mathrm{MeCN}$ ). The presence of one equivalent of acid has no influence on the $\mathrm{CO} / \mathrm{CN}^{-}$ band position and both $\mathrm{ADT}_{\mathrm{CN}}$ and $\mathrm{PDT}_{\mathrm{CN}}$ react with $\mathrm{O}_{2}$ in a similar manner as in the absence of acid (Figure S9). Subsequently, the stronger acids trifluoroacetic acid (TFA, $12.65 p \mathrm{~K}_{\mathrm{a}}$ in $\mathrm{MeCN})$ or paratoluenesulfonic acid (TsOH, $8.3 p \mathrm{~K}_{\mathrm{a}}$ in $\left.\mathrm{MeCN}\right)$ were used. The FTIR spectrum of complex [1] and [2] is dramatically influenced in the presence of TFA or TsOH itself, as after addition of one equivalent of acid, a mean CO band shift of $+94 \pm 1 \mathrm{~cm}^{-1}$ was recorded (Figure 6AB and Table 1). Such high shifts in FTIR spectra are indicative of protonation at the metal center, forming a bridging hydride $(\mu \mathrm{H})$ resulting from the ligand to metal proton transfer. ${ }^{34,35}$ This geometry is comparable to the $\mathrm{H}$-cluster state $\mathrm{H}_{\text {red }}$ that has been shown to bind a $\mu \mathrm{H}$ ligand under ambient conditions. ${ }^{36-38}$ Locked in the $\mathrm{H}_{\text {red }}$ or $\mathrm{H}_{\text {sred }}$ state, $[\mathrm{FeFe}]$-hydrogenase shows a prolonged resistance to $\mathrm{O}_{2} \cdot{ }^{39}$

To further identify the protonated complex [1] and [2], ${ }^{1} \mathrm{H}$ NMR spectroscopy was performed. Figure 6C shows the corresponding low field ${ }^{1} \mathrm{H}$ signals at -19.15 and $-19.75 \mathrm{ppm}$ for complex [1] and complex [2], respectively, which unequivocally confirm formation of the bridging hydride state (along with CNH signals at $-16.25 \mathrm{ppm}$ for complex [2]). ${ }^{40}$ Notably, after formation of the $\mu \mathrm{H}$ geometry, the complexes display no further reactivity with $\mathrm{O}_{2}$ and can be kept under aerobic conditions without notable changes (Figure S11). These observations again lead to the conclusion that the preferred site for oxygen attack is the metal center in the $\mathrm{Fe}^{\mathrm{I}} \mathrm{Fe}^{\mathrm{I}}$ state. Remarkably, these protonated states were also found to be resistant towards $\mathrm{H}_{2} \mathrm{O}_{2}$ as complexes [1] and [2] show unaltered IR spectra after incubation with 1 equivalent of $\mathrm{TsOH}$ 
and varying amounts of $\mathrm{H}_{2} \mathrm{O}_{2}$ (Figure S12). Such observations highlight the similarities between the natural system and the related mimics and hence lay importance on understanding the oxygen induced degradation pathway pertaining $[\mathrm{FeFe}]$-hydrogenases. ${ }^{34,41}$
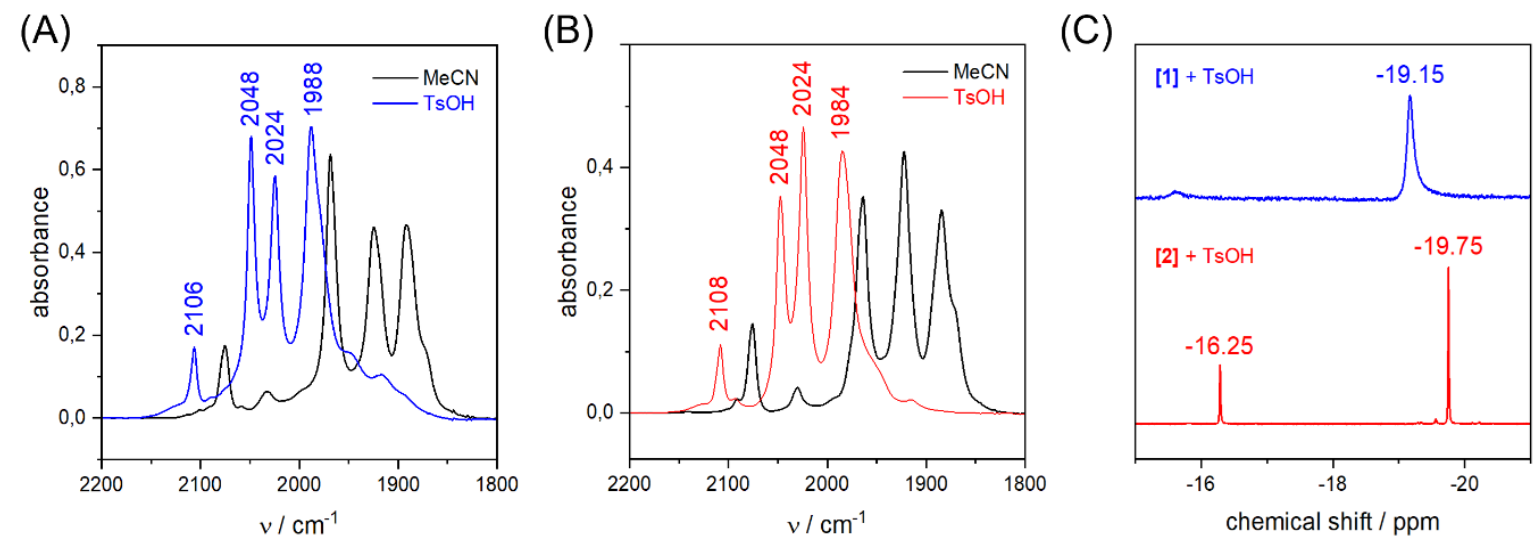

Figure 6 | FTIR spectra of (A) ADT $_{\mathrm{CN}}$ and (B) PDT $_{\mathrm{CN}}$ measured in the presence of one equivalent of TsOH. (C) ${ }^{1} \mathrm{H}$ NMR spectra of $\mathrm{ADT}_{\mathrm{CN}}$ and $\mathrm{PDT}_{\mathrm{CN}}$ obtained upon reaction with 1 equivalent of $\mathrm{TsOH}$.

Enzyme vs. Mimic reactivity. To probe the reactivity of complexes [1] and [2] as part of the $\mathrm{H}$-cluster within functional $[\mathrm{FeFe}]$-hydrogenase, we conducted aerobic deactivation experiments on $\mathrm{CrHydA} 1$ matured with $\mathrm{ADT}_{\mathrm{CN}}$ and $\mathrm{PDT}_{\mathrm{CN}}$. The enzyme was kept under an inert $\mathrm{N}_{2}$ atmosphere to promote auto-oxidation and accumulation of the $\mathrm{H}_{\mathrm{ox}}$ state. Then, $20 \%$ $\mathrm{O}_{2}$ or $5 \% \mathrm{H}_{2} \mathrm{O}_{2}$ were introduced, and the reactivity was monitored by in situ ATR FTIR spectroscopy. In line with the results observed for the active site mimics the enzyme matured with $\mathrm{ADT}_{\mathrm{CN}}\left(\mathrm{CrHydA} 1^{\text {adt }}\right.$, resembling wild-type enzyme) displayed a faster degradation as compared to $\left(\mathrm{CrHydA} 1^{\text {pdt }}\right.$, see Figure 7A). FTIR difference spectra of the $\mathrm{O}_{2}$ reaction revealed a 'damaged' H-cluster species (i.e., $\mathrm{Fe}(\mathrm{CO})_{2} \mathrm{CN}^{-}$with bands at 1930,1985 , and $2095 \mathrm{~cm}^{-1}$ ) that is exclusively observed for $\mathrm{CrHydA} 1^{\text {pdt }}$ (Figure 8A). At lower frequencies, protonation and hydrogen-bonding changes affect the difference spectra. ${ }^{42}$ Figure $\mathbf{8 B}$ highlights the deprotonation of E141 and E144 (1715 and $\left.1695 \mathrm{~cm}^{-1}\right)$ and the protonation of R148 $\left(1682 \mathrm{~cm}^{-}\right.$ ${ }^{1}$ ), potentially accompanied by protein structural changes $\left(1675-1638 \mathrm{~cm}^{-1}\right)$. Surprisingly, both wild-type and cofactor variant show the same signature indicating that proton transfer is not rate-limiting in $\mathrm{CrHydA} 1^{\text {adt }}$ and $\mathrm{CrHydA} 1^{\mathrm{pdt}}$. In agreement with this, the rate of $\mathrm{H}$-cluster degradation in $C r \mathrm{HydA} 1^{\text {adt }}$ and $C r \mathrm{HydA} 1^{\text {pdt }}$ differs considerably when $5 \% \mathrm{H}_{2} \mathrm{O}_{2}$ was introduced (Figure 7B). We presume that hydrogen bonding between the adt ligand and a reduced $\mathrm{O}_{2}$ species in apical position (like the superoxide ligand in $\left.\mathrm{H}_{\mathrm{ox}}-\mathrm{O}_{2}{ }^{-}\right)^{38}$ affects the 
reaction velocity, e.g., by facilitating an intermediate for the next reaction step. Similar second coordination sphere effects were observed for $\mathrm{H}_{\text {hyd }}$ (apical $\mathrm{H}^{-}$ligand) and $\mathrm{H}_{\mathrm{ox}}-\mathrm{CO}$ (apical $\mathrm{CN}^{-}$ ligand), both $\mathrm{H}$-cluster intermediates that are difficult to accumulate in cofactor variant pdt. ${ }^{39,43,44}$ These observations confirm the influence of the bridgehead atom on oxidative degradation and highlight the similar responses of the active site mimics and the H-cluster.

(A)

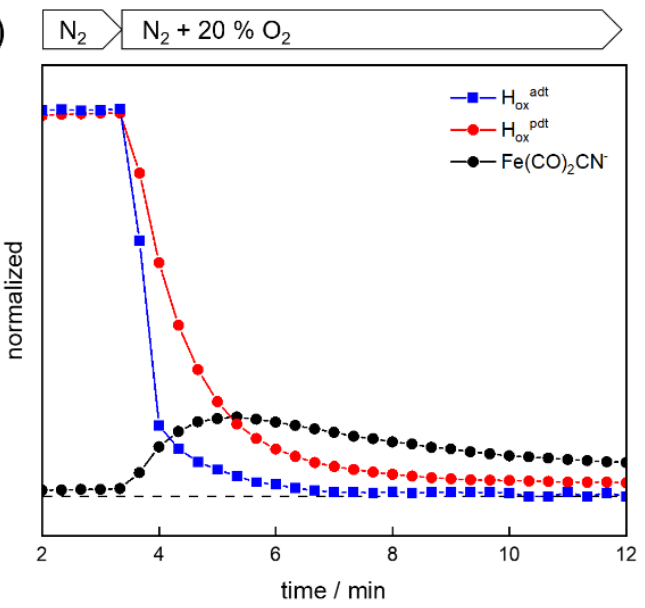

(B)

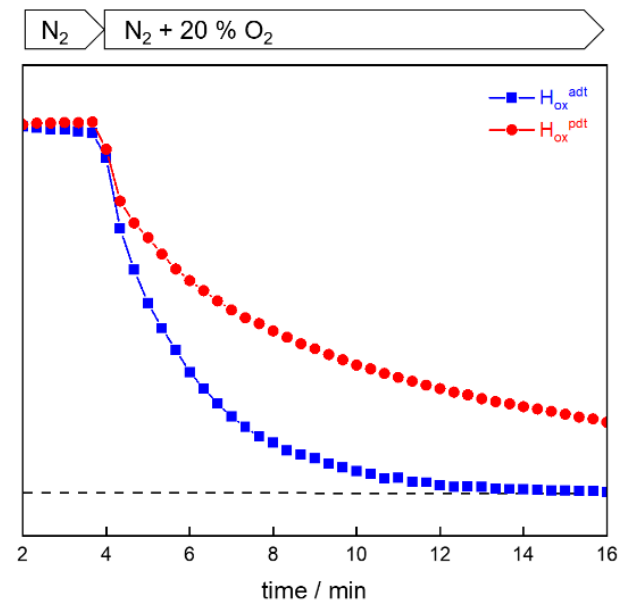

Figure $7 \mid$ Oxidative damage of the $\mathrm{H}$-cluster. The reaction of [FeFe]-hydrogenase $C r \mathrm{HydA} 1^{\text {adt }}$ and $C r \mathrm{HydA} 1^{\text {pdt }}$ with $\mathrm{O}_{2}$ and $\mathrm{H}_{2} \mathrm{O}_{2}$ was monitored by in situ ATR FTIR spectroscopy. The normalized integral of all five $\mathrm{H}$-cluster bands is plotted against time. (A) While $C r \mathrm{HydA} 1^{\text {adt }}$ $\left(\mathrm{H}_{\mathrm{ox}}\right.$, blue) was quickly deactivated in the presence of $20 \%, \mathrm{O}_{2}$ cofactor variant $C r \mathrm{HydA} 1^{\mathrm{pdt}}$ $\left(\mathrm{H}_{\mathrm{ox}}\right.$, red) was deactivated notably slower and formed a transient $\mathrm{Fe}(\mathrm{CO})_{2} \mathrm{CN}^{-}$intermediate (black). (B) The difference in the deactivation kinetics was even more pronounced in the presence of $5 \% \mathrm{H}_{2} \mathrm{O}_{2}$.

(A)

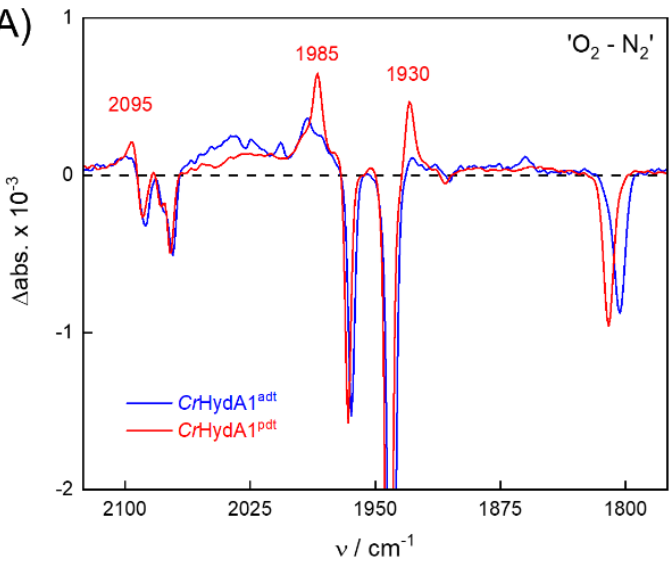

(B)

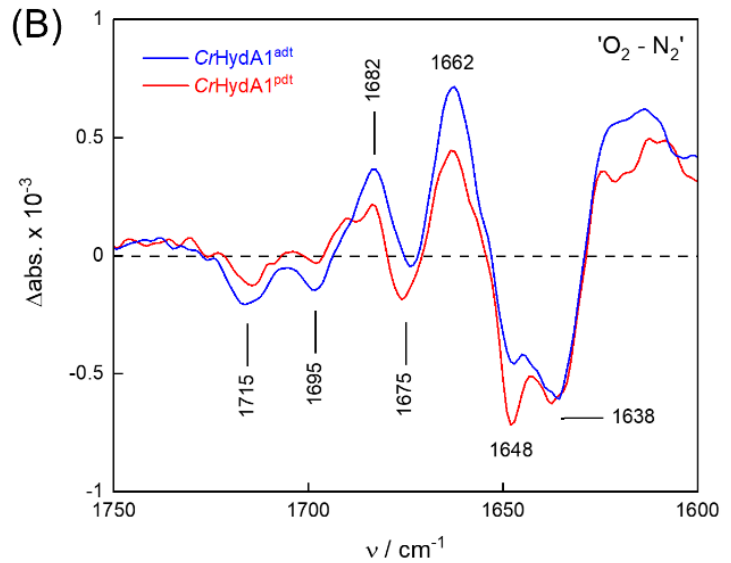

Figure 8 (A) In the $\mathrm{CO} / \mathrm{CN}^{-}$frequency regime of the $\mathrm{H}$-cluster, ' $\mathrm{O}_{2}-\mathrm{N}_{2}$ ' difference spectra show the decrease of the $\mathrm{H}_{\mathrm{ox}}$ state (negative bands). Note the accumulation of a $\mathrm{Fe}(\mathrm{CO})_{2} \mathrm{CN}^{-}$ intermediate exclusive to $\mathrm{CrHydA} 1^{\mathrm{pdt}}$ (red traces). (B) At lower frequencies, bands have been assigned to glutamic acid Glu141 and Glu144 $\left(1715 \mathrm{~cm}^{-1}\right.$ and $\left.1695 \mathrm{~cm}^{-1}\right)$ as well as arginine $\operatorname{Arg} 148\left(1682 \mathrm{~cm}^{-1}\right)$. Other feature may be related to protein structural changes. Note that the traces for $C r \mathrm{HydA} 1^{\text {adt }}$ and $C r \mathrm{HydA} 1^{\mathrm{pdt}}$ are very similar. 


\section{Conclusions}

We have probed active site mimics of [FeFe]-hydrogenase alongside functional enzyme towards $\mathrm{O}_{2}$ sensitivity and their reactivity with various ROS. The results presented here show that the primary deleterious interaction occur at the iron centre and that concomitant $\mathrm{O}_{2}$ binding with electron transfer is required. Thereafter, a rapid degenerative pathway follows which is influenced by the nature of the bridgehead ligand. The ADT $_{\mathrm{CN}}$ complex, which bears an amine bridgehead, is more responsive towards $\mathrm{O}_{2}$, whereas the $\mathrm{PDT}_{\mathrm{CN}}$ complex, which carries a methylene bridgehead, shows diminished reactivity. The experimental results thus suggest that the proposed Pathway II in Figure 5 is more likely. Additionally, the $\mathrm{CO} / \mathrm{CN}^{-}$ligand ratio correlates with an increased reactivity with oxygen species (i.e., $(\mathrm{CO})_{6} \rightarrow(\mathrm{CO})_{5} \mathrm{CN}^{-} \rightarrow$ $\left.(\mathrm{CO})_{4}\left(\mathrm{CN}^{-}\right)_{2}\right)$, highlighting the necessity to incorporate the cyanide ligands in reactivity studies.

In $[\mathrm{FeFe}]$-hydrogenases the fine tuning of an amine headgroup and the $\mathrm{CO} / \mathrm{CN}^{-}$ligands is necessary for the supreme catalytic activity. However, this unique arrangement comes at the expense of oxygen sensitivity. The study thus provides further principles for the oxygen deactivation from a chemical perspective and draws parallels between the H-cluster and its models by direct comparison with the $\mathrm{O}_{2}$ reactivity of functional enzymes $C r \mathrm{HydA} 1^{\text {adt }}$ and $\mathrm{CrHydA} 1^{\mathrm{pdt}}$. Our data clearly emphasize the role of the adt ligand as hydrogen bond donor to intermediates of oxygen deactivation, similar to what has been observed before in hydrogen turnover and $\mathrm{CO}$ inhibition. Remarkably, the active site mimics react with protons resulting in a bridging hydride state and the obtained $\mathrm{Fe}^{\mathrm{II}}-\mu \mathrm{H}-\mathrm{Fe}^{\mathrm{II}}$ state is unresponsive towards $\mathrm{O}_{2}$ and ROS. This observation is in agreement with the reported $\mathrm{O}_{2}$-stability of the common H-cluster intermediate $\mathrm{H}_{\text {red, }}$, wherein a $\mu \mathrm{H}$ ligand is formed at the reduced diiron site and an apical $\mathrm{CO}$ ligand slows down aerobic degradation. The identification of an oxygen stable $\mathrm{Fe}^{\mathrm{II}}-\mu \mathrm{H}-\mathrm{Fe}^{\mathrm{II}}$ state thus might provide a strong chemical precedence for designing new efficient catalysts.

\section{Experimental Methods}

Starting materials and chemicals were obtained from commercial suppliers and used without further purification- Potassium superoxide, hydrogen peroxide ( $30 \% \mathrm{w} / \mathrm{w}$ in water), $p$-toluene sulphonic acid $(\mathrm{TsOH})$ were purchased from Sigma-Aldrich. Trifluoro acetic acid (TFA) was obtained from Acros Organics. 18-crown-6-ether was obtained from TCI chemicals. Molecular oxygen (99.9\%) was obtained from Air Liquide. All solvents were dried and degassed according to standard methods. ${ }^{45}$ 
For the spectroscopic measurements, all manipulations were carried inside an Argon filled glovebox $\left(0.5 \mathrm{ppm}<\mathrm{O}_{2}\right.$ and $\left.0.5 \mathrm{ppm}<\mathrm{H}_{2} \mathrm{O}\right)$. All solutions were freshly prepared prior to experiments. Oxygen was introduced into the sample by purging the solutions with $\mathrm{O}_{2}$ gas out of the glovebox. Other oxidising agents (if stored outside the glovebox) were degassed before experiments by purging with argon for 15 minutes.

Infrared spectroscopy. FTIR spectra were recorded at Shimazu Tracer 100 FT-IR instrument with a MCT detector at $2 \mathrm{~cm}^{-1}$ resolution. Sample solution was prepared in gastight vials and measured in a Specac liquid IR cell with $\mathrm{CaF}_{2}$ windows of $0.05 \mathrm{~mm}$ pathlength. The concentration of the samples was $50 \mathrm{mM}$ in dry $\mathrm{MeCN}$. For experiments with $\mathrm{O}_{2}$, the samples were brought out of the glovebox in septum-sealed vials and purged with $\mathrm{O}_{2}$ for 30 seconds. Experiments with $\mathrm{H}_{2} \mathrm{O}_{2}$ were performed by addition of specific equivalents to the complex solutions via gas tight syringes. In situ ATR FTIR spectroscopy was performed on a Bruker Tensor27 with a Smith Detection ATR unit as described previously. ${ }^{46}$ All protein sample were prepared according to standard procedure. ${ }^{47}$

Mössbauer spectroscopy. Zero-field Mössbauer spectra were recorded by using a constant acceleration spectrometer equipped with a temperature controller maintaining temperatures within $\pm 0.1 \mathrm{~K}$ and a ${ }^{57} \mathrm{Co}$ radiation source in a $\mathrm{Rh}$ matrix. Isomer shifts are referred to $\alpha$-Fe metal at room temperature. Data were fit with a sum of Lorentzian quadrupole doublets by using a least- square routine with WMOSS program. All spectra were recorded as solution in acetonitrile in a plastic sample holder which was frozen in liquid nitrogen. The samples were measured at $80 \mathrm{~K}$ and data were accumulated for about 18 to 24 hours.

NMR spectroscopy. NMR spectra were recorded at room temperature on a Bruker Advanced400 NMR spectrometer $\left({ }^{1} \mathrm{H} 400 \mathrm{MHz}\right)$ and the shifts are reported in parts per million (ppm) relative to the solvent peaks of the deuterated solvent. The concentration of the samples was $50 \mathrm{mM}$ in dry $\mathrm{d}_{3} \mathrm{MeCN}$ and samples were prepared in J. Young NMR tubes inside the glovebox.

Synthesis of complex [1] and [2]. [ $\left.\mathrm{Fe}_{2}(\mathrm{adt})(\mathrm{CO})_{6}\right](0.1 \mathrm{~g}, 0.260 \mathrm{mmol})$ was dissolved in $\mathrm{CH}_{3} \mathrm{CN}(2 \mathrm{ml})$ and cooled to $0^{\circ} \mathrm{C}$. A cold solution of $\left[\mathrm{Et}_{4} \mathrm{~N}\right][\mathrm{CN}](0.085 \mathrm{~g}, 0.55 \mathrm{mmol})$ in $\mathrm{CH}_{3} \mathrm{CN}(1 \mathrm{ml})$ was introduced via gas-tight syringe into the $\left[\mathrm{Fe}_{2}(\mathrm{adt})(\mathrm{CO})_{6}\right]$ solution. The reaction mixture instantaneously turns dark red with evolution of $\mathrm{CO}$ gas. The reaction mixture was allowed to warm to room temperature and further stirred for $3 \mathrm{~h}$. The solvent was removed in vacuo to give a dark red residue. The resulting complex $[1]\left[\mathrm{Fe}_{2}(\operatorname{adt})(\mathrm{CO})_{4}(\mathrm{CN})_{2}\right]\left[\mathrm{Et}_{4} \mathrm{~N}\right]^{2-}$ was transferred to the glovebox and was washed with $6 \mathrm{ml}$ of diethylether, followed by washing with diethyl ether:acetonitrile (20:1). The complex was dried resulting in the dark red solid 
$(0.113 \mathrm{~g}, 68 \%)$. Similar procedure was followed for the synthesis of complex [2] $\left[\mathrm{Fe}_{2}(\mathrm{pdt})(\mathrm{CO})_{4}\left(\mathrm{CN}^{-}\right)\right]\left[\mathrm{Et}_{4} \mathrm{~N}\right]_{2}$.

Synthesis of complex [3] and [4]. A mixture [ $\left.\mathrm{Fe}_{2}(\mathrm{adt})(\mathrm{CO})_{6}\right](0.1 \mathrm{~g}, 0.260 \mathrm{mmol})$ and $\mathrm{Me}_{3} \mathrm{NO}$ (0.0195 g, $0.260 \mathrm{mmol}$ ) was dissolved in $\mathrm{CH}_{3} \mathrm{CN}(2 \mathrm{ml})$ and cooled to $-40{ }^{\circ} \mathrm{C}$. A cold solution of $\left[\mathrm{Et}_{4} \mathrm{~N}\right][\mathrm{CN}](0.028 \mathrm{~g}, 0.260 \mathrm{mmol})$ in $\mathrm{CH}_{3} \mathrm{CN}(1 \mathrm{ml})$ was introduced via gas-tight syringe into the $\left[\mathrm{Fe}_{2}(\mathrm{adt})(\mathrm{CO})_{6}\right]+\mathrm{Me}_{3} \mathrm{NO}$ solution. The reaction mixture turned dark red with evolution of $\mathrm{CO}$ gas. The reaction mixture was allowed to warm to room temperature and further stirred for $3 \mathrm{~h}$. The solvent was removed in vacuo to give a blackish-red, sticky residue. The resulting complex [3] $\left[\mathrm{Fe}_{2}(\mathrm{adt})(\mathrm{CO})_{5}(\mathrm{CN})\right]\left[\mathrm{Et}_{4} \mathrm{~N}\right]^{-}$was transferred to the glovebox and was washed with $6 \mathrm{ml}$ of diethylether, followed by washing with diethyl ether:acetonitrile (20:1). The complex was dried resulting in the dark blackish-red solid $(0.085 \mathrm{~g}, 62 \%)$. Similar procedure was followed for the synthesis of complex $[4]\left[\mathrm{Fe}_{2}(\mathrm{pdt})(\mathrm{CO})_{5}(\mathrm{CN})\right]\left[\mathrm{Et}_{4} \mathrm{~N}\right]$.

\section{Author Contributions}

S.Y. synthesized the complexes, performed FTIR and Mössbauer experiments, and wrote the draft manuscript. S.T.S. performed ATR FTIR experiments and revised the draft manuscript. U.P.A. conceptualised the study, wrote, and revised the draft manuscript.

\section{Conflicts of interest}

The authors declare no conflict of interest.

\section{Acknowledgements}

The authors acknowledge Moritz Senger for pioneering work on in situ ATR FTIR spectroscopy on the reaction of hydrogenase with $\mathrm{O}_{2}$. Further, the authors acknowledge Marco Lorenzi and Gustav Berggren for the production of $C r H y d A 1^{\text {adt }}$ and $C r H y d A 1^{\text {pdt }}$. S.Y. gratefully acknowledges the German Academic Exchange Service (DAAD) for the scholarship. This work was supported by the Deutsche Forschungsgemeinschaft (DFG, AP242/12-1 and STR 1554/5-1 to U.P.A. and S.T.S., respectively). This work was likewise supported by the Fraunhofer Internal Programs under Grant No. Attract 097-602175 and the DFG under Germany's Excellence Strategy - EXC-2033 - Projektnummer 390677874 "RESOLV" (to U.P.A.). 


\section{References}

1 C. Madden, M. D. Vaughn, I. Díez-Pérez, K. A. Brown, P. W. King, D. Gust, A. L. Moore and T. A. Moore, J. Am. Chem. Soc., 2012, 134, 1577-1582.

2 H. Land, M. Senger, G. Berggren and S. T. Stripp, ACS Catal., 2020, 10, 7069-7086.

3 W. Lubitz, H. Ogata, O. Rüdiger and E. Reijerse, Chem. Rev., 2014, 114, 4081-4148.

4 S. Morra, M. Arizzi, F. Valetti and G. Gilardi, Biochemistry, 2016, 55, 5897-5900.

5 M. Winkler, J. Duan, A. Rutz, C. Felbek, L. Scholtysek, O. Lampret, J. Jaenecke, U.-P. Apfel, G. Gilardi, F. Valetti, V. Fourmond, E. Hofmann, C. Léger and T. Happe, Nat. Commun., 2021, 12, 756.

6 H. Land, A. Sekretareva, P. Huang, H. J. Redman, B. Németh, N. Polidori, L. S. Mészáros, M. Senger, S. T. Stripp and G. Berggren, Chem. Sci., 2020, 11, 12789-12801.

7 H. Ogata, W. Lubitz and Y. Higuchi, J. Biochem. (Tokyo), 2016, 160, 251-258.

8 T. Goris, A. F. Wait, M. Saggu, J. Fritsch, N. Heidary, M. Stein, I. Zebger, F. Lendzian, F. A. Armstrong, B. Friedrich and O. Lenz, Nat. Chem. Biol., 2011, 7, 310-318.

9 A. Kubas, C. Orain, D. De Sancho, L. Saujet, M. Sensi, C. Gauquelin, I. Meynial-Salles, P. Soucaille, H. Bottin, C. Baffert, V. Fourmond, R. B. Best, J. Blumberger and C. Léger, Nat. Chem., 2017, 9, 88-95.

10 M. Mohammadi and H. Vashisth, J. Phys. Chem. B, 2017, 121, 10007-10017.

11 J. Cohen, K. Kim, P. King, M. Seibert and K. Schulten, Structure, 2005, 13, 1321-1329.

12 M. T. Stiebritz and M. Reiher, Inorg. Chem., 2009, 48, 7127-7140.

13 J. Esselborn, L. Kertess, U.-P. Apfel, E. Hofmann and T. Happe, J. Am. Chem. Soc., 2019, 141, 17721-17728.

14 S. T. Stripp, G. Goldet, C. Brandmayr, O. Sanganas, K. A. Vincent, M. Haumann, F. A. Armstrong and T. Happe, 6.

15 K. D. Swanson, M. W. Ratzloff, D. W. Mulder, J. H. Artz, S. Ghose, A. Hoffman, S. White, O. A. Zadvornyy, J. B. Broderick, B. Bothner, P. W. King and J. W. Peters, J. Am. Chem. Soc., 2015, 137, 1809-1816.

16 G. Goldet, C. Brandmayr, S. T. Stripp, T. Happe, C. Cavazza, J. C. Fontecilla-Camps and F. A. Armstrong, J. Am. Chem. Soc., 2009, 131, 14979-14989.

17 J. T. Kleinhaus, F. Wittkamp, S. Yadav, D. Siegmund and U.-P. Apfel, Chem. Soc. Rev., 2021, 50, 1668-1784.

18 T. Liu, B. Li, M. L. Singleton, M. B. Hall and M. Y. Darensbourg, J. Am. Chem. Soc., 2009, 131, 8296-8307. 
19 J. Windhager, R. A. Seidel, U.-P. Apfel, H. Görls, G. Linti and W. Weigand, Chem. Biodivers., 2008, 5, 2023-2041.

20 S. Dey, A. Rana, D. Crouthers, B. Mondal, P. K. Das, M. Y. Darensbourg and A. Dey, J. Am. Chem. Soc., 2014, 136, 8847-8850.

21 V. C.-C. Wang, C. Esmieu, H. J. Redman, G. Berggren and L. Hammarström, Dalton Trans., 2020, 49, 858-865.

22 A. R. Finkelmann, M. T. Stiebritz and M. Reiher, Inorg. Chem., 2014, 53, 11890-11902.

23 M. K. Bruska, M. T. Stiebritz and M. Reiher, J. Am. Chem. Soc., 2011, 133, 2058820603.

24 J. F. Siebel, A. Adamska-Venkatesh, K. Weber, S. Rumpel, E. Reijerse and W. Lubitz, Biochemistry, 2015, 54, 1474-1483.

25 H. Li and T. B. Rauchfuss, J. Am. Chem. Soc., 2002, 124, 726-727.

26 F. Gloaguen, J. D. Lawrence, M. Schmidt, S. R. Wilson and T. B. Rauchfuss, J. Am. Chem. Soc., 2001, 123, 12518-12527.

27 A. S. Pereira, P. Tavares, I. Moura, J. G. Moura and B. H. Huynh, 12.

28 S. Mebs, R. Kositzki, J. Duan, L. Kertess, M. Senger, F. Wittkamp, U.-P. Apfel, T. Happe, S. T. Stripp, M. Winkler and M. Haumann, Biochim. Biophys. Acta BBA - Bioenerg., 2018, 1859, 28-41.

29 A. Kubas, D. De Sancho, R. B. Best and J. Blumberger, Angew. Chem. Int. Ed., 2014, 53, 4081-4084.

30 M. Hayyan, M. A. Hashim and I. M. AlNashef, Chem. Rev., 2016, 116, 3029-3085.

31 B. J. Lemon and J. W. Peters, Biochemistry, 1999, 38, 12969-12973.

32 F. Roncaroli, E. Bill, B. Friedrich, O. Lenz, W. Lubitz and M.-E. Pandelia, Chem. Sci., 2015, 6, 4495-4507.

33 J. Noth, R. Kositzki, K. Klein, M. Winkler, M. Haumann and T. Happe, Sci. Rep., 2015, 5, 13978.

34 F. Gloaguen, J. D. Lawrence, T. B. Rauchfuss, M. Bénard and M.-M. Rohmer, Inorg. Chem., 2002, 41, 6573-6582.

35 X. Zhao, I. P. Georgakaki, M. L. Miller, J. C. Yarbrough and M. Y. Darensbourg, J. Am. Chem. Soc., 2001, 123, 9710-9711.

36 S. T. Stripp, S. Mebs and M. Haumann, Inorg. Chem., 2020, 59, 16474-16488.

37 M. Haumann and S. T. Stripp, Acc. Chem. Res., 2018, 51, 1755-1763.

38 S. Mebs, M. Senger, J. Duan, F. Wittkamp, U.-P. Apfel, T. Happe, M. Winkler, S. T. Stripp and M. Haumann, J. Am. Chem. Soc., 2017, 139, 12157-12160. 
39 J. Duan, S. Mebs, K. Laun, F. Wittkamp, J. Heberle, T. Happe, E. Hofmann, U.-P. Apfel, M. Winkler, M. Senger, M. Haumann and S. T. Stripp, ACS Catal., 2019, 9, 9140-9149.

40 A. Jablonskyte, J. A. Wright and C. J. Pickett, Dalton Trans., 2010, 39, 3026.

41 F. Gloaguen, J. D. Lawrence and T. B. Rauchfuss, J. Am. Chem. Soc., 2001, 123, 94769477.

42 M. Senger, V. Eichmann, K. Laun, J. Duan, F. Wittkamp, G. Knör, U.-P. Apfel, T. Happe, M. Winkler, J. Heberle and S. T. Stripp, J. Am. Chem. Soc., 2019, 141, 17394-17403.

43 M. Senger, S. Mebs, J. Duan, F. Wittkamp, U.-P. Apfel, J. Heberle, M. Haumann and S. T. Stripp, Proc. Natl. Acad. Sci., 2016, 113, 8454-8459.

44 M. Winkler, M. Senger, J. Duan, J. Esselborn, F. Wittkamp, E. Hofmann, U.-P. Apfel, S. T. Stripp and T. Happe, Nat. Commun., 2017, 8, 16115.

45 A. P. G. Kieboom, Recl. Trav. Chim. Pays-Bas, 1988, 107, 685-685.

46 S. T. Stripp, ACS Catal., 2021, 11, 7845-7862.

47 J. Esselborn, C. Lambertz, A. Adamska-Venkatesh, T. Simmons, G. Berggren, J. Noth, J. Siebel, A. Hemschemeier, V. Artero, E. Reijerse, M. Fontecave, W. Lubitz and T. Happe, Nat. Chem. Biol., 2013, 9, 607-609.

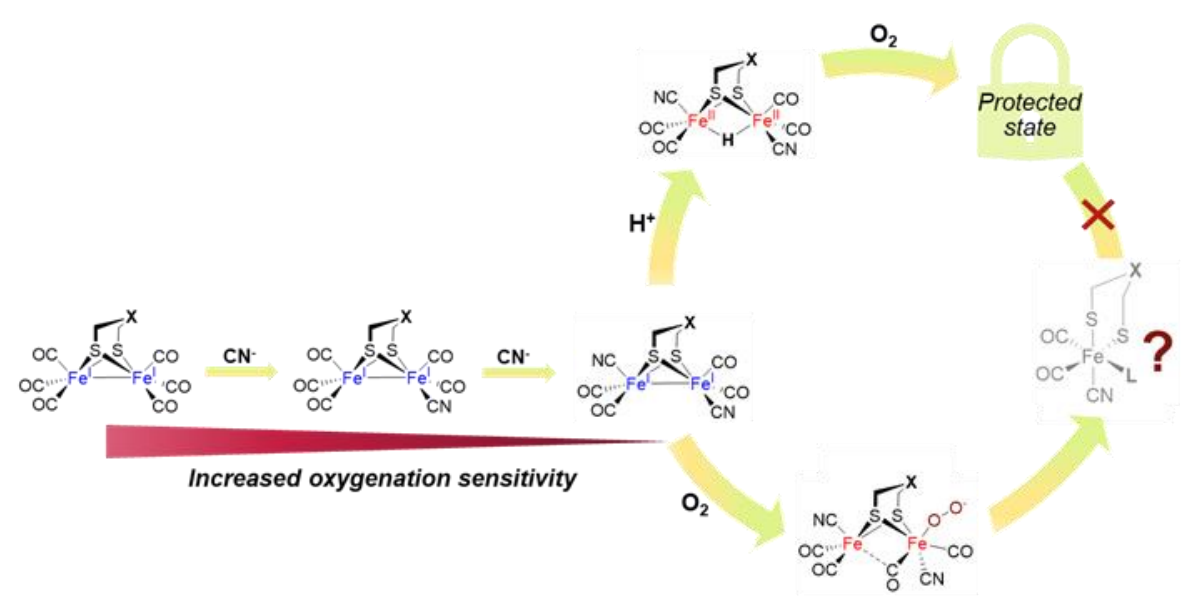

Table of Contents 